\title{
A VIGOROUS AFFIRMATION OF LIFE Slaves in the Face of Dehumanization
}

FOR A SLAVE LIVING UNDER THE SYSTEM OF CHATTEL SLAVERY IN THE AMERICAN SOUTH DURING THE NINETEENTH CENTURY, AVENUES OF SELF-EXPRESSION WERE EXTREMELY LIMITED. ONE OF THE FEW WAYS SLAVES COULD EXERT CONTROL OVER THEIR OWN LIVES WAS THROUGH SINGING AND DANCING. THESE ARTS GAVE SLAVES A CHANCE TO RELIEVE STRESS AND ESTABLISH A CULTURE THROUGH THE CREATION OF MUSICAL INSTRUMENTS, SONGS, AND DANCES. ALL OF THESE CONTAINED HINTS AT THE TRUE NATURE OF SLAVES' FEELINGS TOWARDS THE SYSTEM THAT OPPRESSED THEM, FEELINGS THAT THEY HAD TO FREQUENTLY REPRESS. HOWEVER, DESPITE SLAVES' EFFORTS TO MAKE THIS CULTURE ENTIRELY THEIR OWN, MASTERS TRIED TO FIND WAYS TO USE IT TO THEIR ADVANTAGE INSTEAD OF TO THE SLAVES' BENEFIT. THE RESULTING COVERT POWER STRUGGLE SOMETIMES ENDED IN FAVOR OF THE MASTERS, TAKING THE FORM OF REGULATIONS ON SLAVES DANCES, REQUIREMENT OF THE PERFORMANCE OF SONGS AND DANCES FOR THE MASTERS' ENTERTAINMENT, AND EVEN ABUSE OF SLAVES BY USING THEIR OWN ARTS. ULTIMATELY, HOWEVER, SLAVES EMERGED VICTORIOUS BECAUSE OF THE HIDDEN MESSAGES IN THEIR SONGS AND DANCES. THOUGH THIS METHOD OF COPING COULD NOT ERASE ALL THE MASTERS DID, IT WAS AT LEAST ONE GLIMMER OF HOPE. 
Nineteenth-century chattel slavery was designed to dehumanize those who were enslaved. Masters denied African slaves and their descendants their native languages, religions, and cultures, forcing the English language, Christianity, and American culture upon them. The stories of the unthinkable horrors of slavery are kept in the words of runaway slaves who published accounts of their lives in slavery, in interviews with former slaves conducted by the Works Progress Administration (WPA), and between the lines of planters' personal diaries. Also contained within these important primary sources are the stories of slave resistance, albeit more apparent in the slave narratives than in planters' journals.

Slaves had very few avenues to assert their autonomy and humanity on plantations, but whenever they found a way to do so, they did. Most often, slaves tried to preserve as much of their heritage from African tribes as they could. For example, in South Carolina, when many different tribes came together on plantations, they held onto the grammatical structures of several of their tribes, adapted English vocabulary, and created a new language called "Gullah." A more widespread example of slaves holding onto African traditions was the appearance of songs and dances in a variety of times and places on plantations. All three primary sources above contain a plethora of instances in which slaves sang, danced, or did both. While it would initially seem that slaves used their dancing and singing to assert their own type of power during celebrations and ceremonies, masters often tried to exploit slaves' dances and songs, thus asserting even more authority over slaves. Despite masters' efforts, slaves still derived great benefit from singing and dancing, in that it gave them a way to release stress and frustration about being enslaved.

There were few avenues for slaves to assert their sense of self and semblance of power on a plantation. One of the most important ones was through music and dance, which gave slaves the opportunity to create their own pieces of culture to replace those that masters had taken away from them. Slaves made music in a variety of different ways and created different types of music for different purposes. The interviewees of the WPA Narratives give great insights into how creative slaves had to be when it came to making their instruments. For example, to make flutes, "dey'd take a de buffalo horn and scrape it out." 3 In addition to making their own instruments, slaves also had access to fiddles, ${ }^{4}$ banjoes, ${ }^{5}$ and in two independent cases a guitar ${ }^{6}$ and a piano. ${ }^{7}$ These instruments were important for creating melodies in slave music.
However, what made music "strictly southern," 8 as Frederick Douglass put it, was the existence of drums or a "Juba beater." 9 On some plantations, they would "take pieces a sheep's rib or cow's jaw or a piece iron, with a old kettle or a hollow gourd and some horsehairs to make de drums." ${ }^{\text {I }}$ When even these supplies were not available, "everybody sang and one or two would beat on tin pans or beat bones together" in order to make music. ${ }^{\text {II }}$ Drums were a distinctly African musical instrument, which separated music slaves made from music their masters probably made and as a result gave slaves a distinct sense of a culture that was their own. The use of drums coupled with a long-standing tradition of African ceremonial dances helped to give rise to the importance of dance in slave culture. ${ }^{\mathrm{I2}}$

A variety of instruments and sounds led to the creation of different types of songs. Even without instruments, slaves sang in the fields while they worked in order to pass the time and keep pace with each other. Several former slaves remembered specific examples of work songs. One of them had the lyrics 'I'se wukkin; on de building,' and hits a sho' foundation, and when I git done, I'se goin' home to Heb'en." ${ }^{13}$ Not only did this song serve as one to sing during long days in the fields, but it also crossed over into another genre of slave music - religious worship. ${ }^{\mathrm{I}}$ These songs could generally be sung anywhere, not just at religious services. Like the work song mentioned above, the central theme of many of these songs was salvation. WPA interviewee Ellen King sang a version of the song "Down by the Riverside" during her interview, and it appeared as follows:

\author{
Down by the riverside \\ Jesus will talk and walk, \\ Ain't going to study the world no more, \\ Ain't going to study the world no more, \\ For down by the river side, \\ Jesus will talk and walk. ${ }^{15}$
}

The song focuses on following Jesus's teachings and example so that one does not have to continue to live in His earthly kingdom anymore. The lines "ain't going to study the world no more" indicate that the singer is looking forward to going to heaven and leaving this world behind. Similarly, the song "Come Change My Name," sung by Estella Jones in her WPA interview, focuses on receiving grace from God. The singer in this song calls upon the "bright angel" and on "sweet Jesus" to "come change my name from Nature to Grace." ${ }^{16}$ Like the line "ain't going to study the world no more," the idea that a person is chang- 
ing from "Nature" (or this earth) to "Grace" (heaven) invokes the idea of salvation. This focus on the idea of salvation clearly shows how slaves used both religion and their music as ways to cope with and find escape from the harshness of their lives.

While religious songs and dance songs were kept relatively separate from one another, as many viewed dancing as sinful, ${ }^{17}$ there was potential for overlaps in the sound of these songs. In one instance, Sarah Douglas remarked that she recalled hearing some people singing the song "Fly away, fly away," "an hit sounded jes like a dance chune." ${ }^{8}$ The similarity of sound was due to the fact that the instruments used to create the music in the first place, especially the drum, were similar. Despite the resemblance in sound, dance songs were extremely different in content than religious songs because they focused more on the realities of slave life rather than the hope of salvation or escape from this world. ${ }^{19}$ One such song focused on the reality of illness ${ }^{2 \circ}$ in slaves' lives and had the lyrics "Mamma's got de whoopin' cough, Daddy's got de measles, Dat's whar de money goes, Pop goes de weasel." ${ }^{21}$ By directly talking about a problem plaguing their lives, slaves were trying to take ownership of the situation. Despite the upbeat and singsong tone that accompanies this song (as seen in the children's nursery rhyme "Pop Goes the Weasel"), ${ }^{22}$ these lyrics convey a sort of resignation to the fact that disease is part of life. There is no salvation narrative here in leaving the world behind, but the release valve for the emotions of fear and frustration comes from the fact that the listener is most likely dancing. Instead of a spiritual outlet for pain, dancing provides a physical outlet to cope.

The use of real life situations is evident in another dance song, which reads:

Run nigger run, de patterrollers ketch you -

Run nigger run, fer hits almos' day,

De nigger run, de nigger flew; de nigger los'

His big old shoe. ${ }^{23}$

This song's end result is much more positive than the previous one, especially since it involves a slave who has left the plantation without the master's permission. His fear that the "patterrollers" (paddy rollers, or patrol agents) will find him indicates that he does not have a pass to leave, but did so anyway. It seems that the slave makes it back to his plantation relatively unharmed, except for the fact that he lost one of his shoes, which is a small price to pay for avoiding getting whipped by the patrolmen. While this song does make reference to the restriction of slaves' freedom of movement, it fights against this limitation since the slave ultimately avoids getting caught. In this case, both the song and the dance are outlets for coping with enslavement.

In addition to songs that were imbued with certain messages and goals, some dance songs could also be classified as "unmeaning songs, composed rather for its adaptation to a certain tune or measure than for the purpose of expressing any distinct idea." ${ }^{24}$ These songs were purely meant for the purpose of dancing and having fun. There were obviously few opportunities for slaves to try to forget completely about their enslavement and enjoy the company of their family and community, and so "nonsensical" songs that were "full of melody" 25 were welcome as another means of dealing with living and working on a plantation. An example of such a song is as follows:

'Ebo Dick and Jurdan's Jo,

Them two niggers stole my yo'.

Chorus. Hop Jim along,

Walk Jim along,

Talk Jim along,' \&c.

'Old black Dan, as black as tar,

He dam glad he was not dar.

Hop Jim along,' \&c. [sic] ${ }^{26}$

The repetition of the two lines in the same rhythm followed by the chorus would have made it easy for the person singing this song to improvise verses as they saw fit, according to perhaps what was happening on the plantation or in reference to stories that slaves told each other. ${ }^{27}$ In songs like this one, the dancing could continue even after the fiddle player had stopped playing because of the system of "patting." ${ }^{28}$ Patting is "striking the hands on the knees, then striking the hands together, then striking the right shoulder with one hand, then the left with the otherall the while keeping time with the feet, and singing." ${ }^{29}$ The rhythm of these songs had to follow the rhythms of patting, which standardized the music, and thus made it easier to choreograph dances.

As with music, slaves came up with and appropriated different types and styles of dancing. There was a lot of overlap between the types of dances whites and blacks did, such as "square dances, [...] the Virginia Reel, and the 
i round dances like the Schottischa, Polka, waltzes, and all them. ${ }^{{ }^{\prime \prime} \circ}$ It is not at all surprising that the dance forms of these two groups came together since each group could observe the habits of the other. Theoretically, a slave serving at a white wedding could see the guests doing a particular kind of dance-say, the Virginia Reel-and then bring it back to his or her own community. From there, dances could evolve and change if slaves forgot the exact choreography of dances or decided to change certain steps to reflect African dances or simply because they wanted to change them. One important piece of the development of slave dances was the avoidance of crossing one's feet because "dancin' ain't sinful iffen de foots ain't crossed." ${ }^{3+}$ This characteristic recalls the tension that existed between dance and religion. It was probably an answer to those who considered dancing to be contrary to religion, though it is probable that this change was not enough for those who were predisposed to thinking that dancing was a heathen practice.

Another important element of slave dancing was the aspect of competition. "Cake walkin"'32 was one of the most famous developments of slave dancing. It was generally performed in couples and "de couple dat danced de best got a prize" 33 (the story goes that the first ever prize was cake). It would appear that cakewalking was a form of dance unique to southern plantations, ${ }^{34}$ showing the creativity of slaves to be resourceful in coming up with coping mechanisms for enslavement. The cakewalk was not the only competition during slave dances. Another competition involved gathering a few slaves together who "would jump up and see how many time he could kick his feets 'fore dey hit de groun." ${ }^{35}$ This competition seemed less formal than a cakewalk, but it still inspired its competitors to try to outdo one another in dancing ability. In trying to become the superior dancer, competitions such as the one William Adams mentioned would have given a slave a personal goal to reach that was not related to the work that he or she did on the plantation. It became something particularly for slaves that no one else could touch. Winning a competition surely gave the winner a sense of pride that masters, through the institution of slavery, sought to deny.

As important as the creation of these two art forms was, equally as important was when slaves sang and danced, and for what purpose. The variety of times slaves would use music and dance shows just how important these two pieces of culture were to slaves since they seemed to try to work them into their lives whenever they could. Marriage ceremonies were an exciting part of slave life, despite the fact that slaves were not legally allowed to be married. In the WPA narratives, anyone who mentioned a wedding was almost sure to mention that there was a "big dance" ${ }^{36}$ when there was a slave union. ${ }^{37}$ These happy times were moments when the community could come together to celebrate a bond between two people, and there was no better way to bring people closer together than sharing the art forms that connected the slave community.

Since religion was one of many coping mechanisms people used to come to terms with human mortality, and since religion was so important to slaves as evidenced by the number of religious songs they sang, it is not at all surprising that music was an integral part of slave funerals across many plantations. On one plantation, slaves would stay with the recently deceased until he or she was buried and "sung and prayed" to keep cats, which were considered bad luck, away from the corpse. ${ }^{38}$ Beyond this mingling of Christianity and African traditions, singing was also part of the funeral service itself. Some of the songs were meant to invoke the idea of salvation, like many other religious songs. One such song called on angels to "bear me away on your snowy wings, to my immortal home." 39 Paul Smith remembered "when de preacher had done said a prayer, dey all sung: I'se Born to Die and Lay Dis Body Down," 40 and Alice Hucheson remembered a song that her community used to sing while burying the deceased. The song called attention to the fact that everyone will eventually die, but instead of trying to predict who will be the next, we should "prepare to meet our God" and ask God to give us Grace to "make us fit at las' to die." ${ }^{4 \mathrm{I}}$ The universality of the experience of death is similar to the way other slave

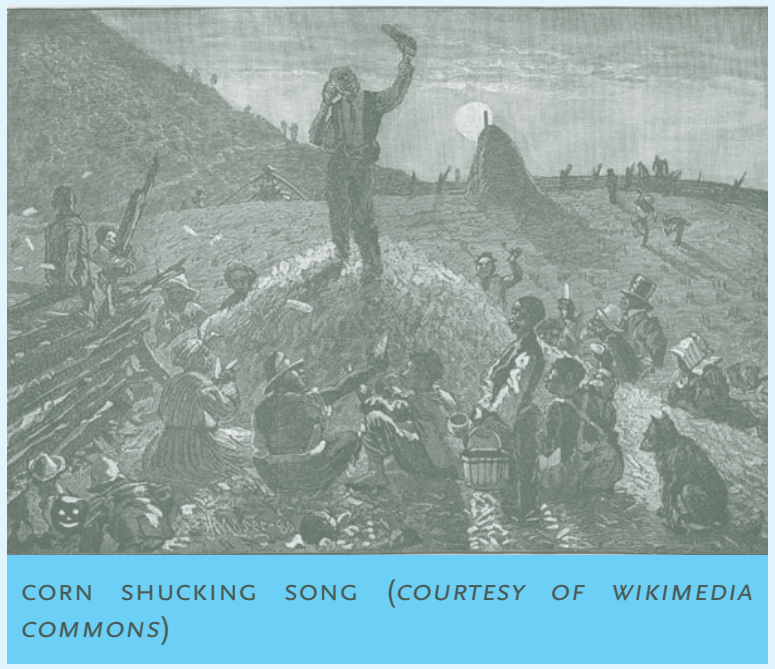




\section{"Music was truly meant to connect all parts of the community and foster ties that all too often were rare for slaves, since they could be broken through either death or}

sale to another master."

songs appealed to universal suffering or daily activities. Music was truly meant to connect all parts of the community and foster ties that all too often were rare for slaves, since they could be broken through either death or sale to another master. ${ }^{2}$

The most universal of all experiences on a southern plantation was the work that slaves were forced to do. As previously discussed, work songs were their own genre of music for slaves, as they were performed without musical accompaniment since the slaves were obviously occupied doing other tasks besides playing instruments. There were several purposes to these songs. One such purpose was to set a pace for their work and pass the time in the fields. ${ }^{43}$ Another was "a means of telling the overseer, in the distance, where they were and what they were about." 44 Judging by the volume of the song, the overseer could tell where the workers were in the field without necessarily having to measure their progress. ${ }^{45}$ Finally, work songs could help to motivate slaves to wake up in the morning and go to work. The following song conveys the universality of suffering and probably helped slaves remember that they were not alone:

It's a cool and frosty mornin'

And de niggers goes to work,

With hoes upon dey shoulders,

Without a bit of shirt. ${ }^{46}$

Several devices are used to remind individual slaves that the community understands what they are going through. The use of the plural shows that the listed hardships are problems that everyone has. Plus, the song directly states what exactly the hardships are that everyone is going through, namely the cool temperature, the earliness of the day, the hard labor they will have to do, and the lack of adequate clothing for the season. Since the singers are not hiding from the problems they face, and are on the contrary drawing attention to them, this song can be interpreted as the slave community critiquing the plantation system.
Since music and dancing were such key parts of helping slaves cope with their suffering, during their time off, such as after work was over, Saturday nights, Sundays, and holidays, music and dancing were nearly always present. The times of dances on the weekends varied from plantation to plantation. On some, they would be "after work" 47 or "in de evening when de work was done." ${ }^{8}$ On others it would be on a Sunday and "rarely on Saturday." ${ }^{49}$ What was a fairly universal experience, however, was the corn shucking festival. Traditions varied, but most ex-slaves in the WPA Narratives remembered these festivals very fondly. Generally, "one negro would sit on the fence and lead the singing, the others shuck on each side," ${ }^{\circ \circ}$ singing songs like "Old Liza Jane" and "Susan Jane," ${ }^{\mathrm{I}}$ and this would continue until the entire task was finished..$^{52}$ Sometimes, it would be a competition between two teams to see who could finish first. ${ }^{53}$ After the corn shucking itself was over, there would be a feast and dancing "until daybreak." ${ }^{4}$ Even though the slaves were obviously working for the master's benefit while they were shucking corn, this holiday gave them a chance to come together as a community for a day of work that was slightly less strenuous than normal.55

Christmas was another important holiday for slaves. Solomon Northrup wrote:

It was Christmas morning - the happiest day in the whole year for the slave. That morning he need not hurry into the field, with his gourd and cotton-bag. Happiness sparkled in the eyes and overspread the countenance of all. The time of feasting and dancing had come. The cane and cotton fields were deserted. That day the clean dress was to be donned - the red ribbon displayed; there were to be re-unions, and joy and laughter, and hurrying to and fro. It was to be a day of liberty among the children of Slavery. Wherefore they were happy, and rejoiced. ${ }^{56}$

This passage gets at the very essence of the Christmas holidays for slaves. Unlike the corn shucking festival, in which the festivities were explicitly linked to working for the master, this time was the slaves' own time. There was always a huge dance following a Christmas meal, which 
9 naturally brought together the entire slave community as one..$^{57}$ These happy times, when slaves seemed temporarily free from the master's influence and the overseer's watch, were the ultimate way of relieving tensions from the year and reinforcing community bonds, which is exactly what songs and dances were meant to do. But, this cheerful season did have a darker side to it.

Slaves unquestionably had the upper hand in the creation of music and dances during festivities. However, masters often tried to take this part of slave culture away from slaves and use it to benefit themselves for either entertainment or for disciplinary purposes..$^{8}$ During holidays, masters continued to remind slaves that just because they were not working did not mean that they had complete freedom to do as they pleased. Often, masters would go see slave dances on Christmas 'an' see de one what dances de bes'. Marster an Mistis laug fit to kil at de capers us cut." 59 This visit from the master and mistress seems like an invasion on the slaves' privacy and privilege of freedom during the holiday season. The master's mocking is especially poignant here since dancing was an event that was meant to bring the community together and allow slaves to release some of the tension felt towards masters. Laughter from the master probably only added to the resentment. Also, the fact that the master was the one judging which dancer was best in competitions took away some of the autonomy these competitions may have brought to slaves when master were not the ones judging.

Douglass wrote about a theory as to why masters felt it necessary to interfere at holidays as well as what the true purpose of giving slaves time off was. He believed that

To enslave men successfully and safely it is necessary to keep their minds occupied with thoughts and aspirations short of the liberty of which they are deprived. A certain degree of attainable good must be kept before them. These holidays served the purpose of keeping the minds of the slaves occupied with prospective pleasure within the limits of slavery. ${ }^{60}$

Therefore, giving slaves time off was not to be regarded as the happy time that Northrup made it out to be; instead, it was just an illusion to keep slaves willing to work with the promise of having a holiday again soon. Holidays were not truly the slaves' own time, as this time was a manipulation by the masters. By making appearances at slave dances during the holidays, the masters were on one level trying to assert their dominance over slaves during the holiday itself, and on another level, trying to reign in control of music and dance.

This behavior was not exclusive to just holidays. Masters and Mistresses alike would come to slave quarters any time there was a chance for slaves to have a taste of independence. Even though they could "have all de fun [they] wanted on Sa'dday nights, [....] sometimes our Mistess would come down early to watch us dance." ${ }^{\text {"II }}$ These times were nominally for the slaves, but in practice were not. Margaret Thornton, who was very young when she was enslaved, did not remember much except for the fact that "dey herded us together an' make us sing a heap of songs an' dance, den dey clap dere han's an' dey sez dat we is good." ${ }^{\prime 2}$ The number of times that the master and mistress must have called the slaves together for a performance must have been great for her to recall this information so strongly. The masters were trying to take the art form that the slaves had created for themselves and turn it into entertainment for the masters. This phenomenon was a direct affront to the already limited autonomy of slaves.

Another way in which masters limited the ability of slaves to use their own culture was that before slaves could organize a dance, they would have to ask their masters for permission first. ${ }^{63}$ On some plantations, there was a separate "house" that slaves held their dances in, ${ }^{64}$ but on others, the dances seemed to take place near the slave quarters. ${ }^{65}$ The inability to come together in their own quarters was particularly dehumanizing because it meant that slaves did not even have control over what activities went on in their homes.

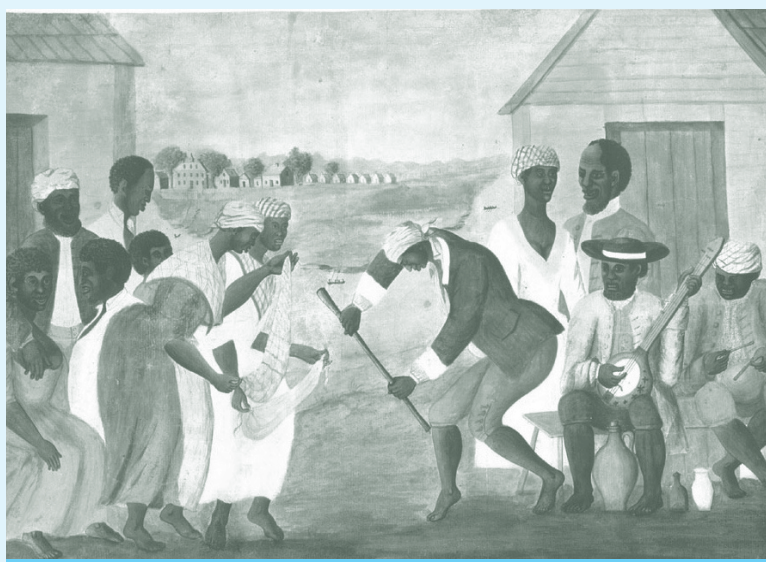

SLAVES DANCE TO THE MUSIC OF BANJO (COURTESY OF WIKIMEDIA COMMONS) 
In addition to trying to control slaves' singing and dancing, some masters also chose not to acknowledge that it even happened. Landon Carter was one such master, as evidenced by two pieces of information. First, there is "no single reference to it in all his diaries," yet he appeared to have acknowledged of the types of instruments slaves used when making music. ${ }^{66}$ He wrote about the instruments when he was making fun of King George, and talked about the "Quaqua," "Barafoo," and "Banjers." ${ }_{7}$ This obscure reference proves that Carter knew enough about slave music to write satirically about it. His lack of discussion about the music his own slaves made raises some question as to why he omitted this from his otherwise very detailed diaries. Carter most likely did not want to draw attention to this particular aspect of life on his plantation because it would force him to admit "how much [he] shared the domain he chronicled with the bearers of a culture alien to the literary ethos of the diary." ${ }^{68}$ In other words, saying that slaves had music and culture meant that Carter's slaves were more civilized and less in need of a benevolent patriarch than he would care to admit. Carter thrived on being in control of every single aspect of life on his plantation, ${ }^{69}$ and so the thought of the existence of something he could not control would have been unbearable to him. Instead of wresting control from the slaves like other masters did, Carter adopted the attitude of "if I act like it does not exist, then it does not exist."

Although frustrating to slaves' efforts to carve out a piece of culture for themselves, it is not particularly surprising that masters made their slaves sing and dance for the former's entertainment or ignored them for the sake of pretending to have control. The extreme cruelty of the masters was more apparent when they took the culture that the slaves had worked so hard to create for themselves, turned it on its head, and used it for punishment against slaves. A mild case of this act was reported by Bernice Bowden, who said that her master "used to come to the quarters and make us chillum sing. He make us sing Dixie. Sometimes he make us sing half a day. Seems like Dixie his main song. I tell you I don't like it now. But have mercy! He make us sing it." ${ }^{\circ}$ The duration that Bowden was required to sing for shows that this was beyond just simple entertainment. Of course, Bowden may have been using hyperbole when she said "half a day," but her reason to use this technique would have been to emphasize how much she had to do this. Since Dixie is such a strongly pro-south song, the repetition of it was intended to remind slaves who had the power.
A step up in the severity of this style of punishment would be when a master forced a boy who did not want to perform for his master to stand "barefooted on a hot piece of tin." ${ }^{71}$ Margaret Thornton, the interviewee providing this story noted, "believe me he did dance." ${ }^{72}$ The penalty for not wanting to dance was extremely severe and was torture for this young boy. Though Thornton does not tell her former master's reaction to this punishment, one can imagine that he was amused by it since he got the "dance" he wanted and was reinforcing the view that he was the one in charge of the situation. Slaves singing and dancing (or refusing to) independently of the master was the greatest affront to a master's authority. Whether or not this boy wanted to dance was irrelevant to the master; he wanted him to dance, so the boy was going to dance so as to show that the master's will would not be thwarted in any case.

The worst offense of forcing slaves to dance to entertain the master as well as punish the slaves was committed by Edwin Epps, Solomon Northrup's former master. The account that Northrup gives in his narrative is absolutely horrifying. Some nights, Epps would be in a "dancing mood" and would call all of his slaves into a large room. He then would cry out "Dance you d-d niggers, dance," [sic] and all would have to dance "no matter how worn out and tired [they] were." 73 If anyone "dared to rest a moment, or even stop to catch his breath," Epps would whip him. ${ }^{74}$ Even when Epps had stopped dancing, he still forced the slaves to continue well into the night and early hours of the morning. ${ }^{75}$ Not only was Epps whipping his slaves, but he was also depriving them of sleep. They had been awake all day working strenuously, then had to push themselves to continue to dance lest they be whipped by Epps, and then were expected to continue to work for the entirety of the next day. Obviously there was nothing that the slaves could do to stop Epps from behaving in this depraved manner. Not even his wife was able to stop his, as Northrup sarcastically remarks, "uproarious pranks." ${ }^{6}$ The slaves were clearly at the whim of their master. They had lost control over the culture that they sought to create for themselves as an outlet to vent frustration at their situation, but instead wanted to "cast [them]selves upon the earth and weep" 77 because this culture had been turned against them. Abuse of this sort only augmented the already trialfilled life of a slave.

Though not as physically horrific as the treatment Epps inflicted on his slaves, this next case of whites taking advantage of slave dancing is still extremely cruel. Some slave traders realized that when slaves looked happier, 
people were willing to pay higher prices. William Wells Brown wrote in his narrative that his job was to make slaves look happy by "[setting some] to dancing, some to jumping, some to singing, and some to playing cards [....] to make them appear cheerful and happy." ${ }^{8}$ This practice was twisted in more ways than one. Brown himself was a slave, and therefore he had to prepare men and women in the same situation as he himself was in for sale, "often [...] when their cheeks were wet with tears."79 Furthermore, these slaves on the auction block had to use the parts of their culture that were supposed to give them relief from the horrors of slavery in order to sell themselves into the horrors of slavery. They obviously had no choice in the matter, and as Brown noted, were deeply upset by this charade. So they resisted in the only way they could; through song. Brown said that he heard the slaves who had been sold into the deep south sing the following:

\author{
"See these poor souls from Africa \\ Transported to America; \\ We are stolen, and sold to Georgia -- \\ Will you go along with me? \\ We are stolen, and sold to Georgia -- \\ Come sound the jubilee! \\ See wives and husbands sold apart, \\ Their children's screams will break my heart; -- \\ There 's a better day a coming -- \\ Will you go along with me? \\ There 's a better day a coming, \\ Go sound the jubilee! \\ O, gracious Lord! when shall it be, \\ That we poor souls shall all be free? \\ Lord, break them slavery powers -- \\ Will you go along with me? \\ Lord, break them slavery powers, \\ Go sound the jubilee! \\ Dear Lord, dear Lord, when slavery '1l cease, \\ Then we poor souls will have our peace; -- \\ There 's a better day a coming -- \\ Will you go along with me? \\ There 's a better day a coming, \\ Go sound the jubilee!" 80
}

The lyrics of this song do not leave anything to the imagination whatsoever. They are full of the pain of being stripped of humanity and separated from loved ones, as well as full of hope for the day when slavery ends. The slaves owned their situation as best they could in the face of having even their songs and dances taken from them.
Although masters did try to appropriate slave songs and dances for their own uses, slaves still ended up with the upper hand, especially through their music, as seen in the case of the slaves sold south in Brown's narrative. Slaves often found comfort and benefit in their ability to make music. Northrup was able to play the violin, and in his narrative, he states that he "scarcely can conceive how [he] could have endured the long years of bondage" without it. ${ }^{81}$ In addition to giving him emotional comfort, he also reaped material rewards from the various times he was paid to go play at other plantations. Even at that, the psychological benefits from being "relieved [...] of many days' labor in the field, [...] and [...] away from the presence of a hard master"82 cannot possibly be quantified in any way. So despite the fact that Northrup's talents could put him at the mercy of his master when he was in a "dancing mood," they were also a form of escape integral to Northrup's well being. Douglass also figured out a way to derive benefit from his musical abilities. To relieve hunger pains, Douglass would often sing. One of his mistresses, upon realizing this, would give him food "when she heard [him] singing under her window." ${ }^{3}$ In this way Douglass got twice the benefits of singing: he found a way to comfort himself when he was hungry, and he found a way to invoke pity in his mistress so he could get food and dispel the hunger in reality. Douglass used the value masters placed on being entertained to his own benefit, thus untwisting the twist masters had placed on slave culture.

Beyond manipulating the system back in their favor, slaves also sang songs that contained messages that masters either did not see or simply ignored. For example, to call a religious meeting, "when de niggers go round singin' 'Steal Away to Jesus,' dat mean dere gwine be a 'ligous meetin' dat night." ${ }^{4}$ The reason for this secrecy is because "de masters 'fore and after freedom didn't like dem ‘ligious meeintgs." ${ }^{85}$ Not only did slaves continue to have these meetings despite their masters' objections, but they planned them right under their noses without the masters even knowing. Wilson did not make any reference to the fact that these slaves ever got caught having these meetings, or that masters ever made the connection between the meetings and the song, so it is a reasonable assumption that the slaves had the upper hand here.

Also, a rather well known use of song to convey a hidden message was slaves' use of the genre of religious songs to talk about wanting to be free or about going to freedom. Douglass mentions in his narrative two songs that were 
clearly about going to the North to escape from slavery, but that no one realized this was the meaning behind these songs. These songs contained references to being "bound for the land of Canaan" and the command to "run to Jesus, shun the danger" for "I don't expect to stay much longer here." ${ }^{86}$ On the surface, these are innocuous songs that show how slaves seem to have embraced Christianity and are understandably looking forward to going to heaven. As Douglass points out though, this was a veiled message targeted at the masters. Hiding their message behind religion allowed slaves to be able to vent their anger at their masters for keeping them enslaved and express their desire to be free without getting into trouble. It also prevented masters from fully appropriating it into entertainment for themselves, for even if the master forced the slave to sing the song, the slave would always know the true meaning of the song, and could derive great satisfaction from the fact that the master did not know the real value of the lyrics.

Religious songs were not the only songs used to convey sometimes thinly veiled dissatisfaction. One song that slaves sang during the holidays appeared to be giving first line describes the fact that someone wants to make a hoecake, the second line describes the hoecake, the third line describes the baker throwing the hoecake on some part of a slave's body, and the fourth line says what happens after one performs the action of the third line. ${ }^{88}$ Take for example the third verse:

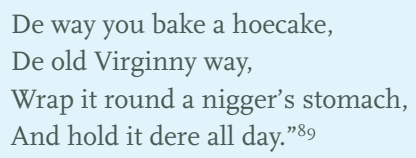

Obviously, no one is actually baking hoecake on a slave, but the line serves to show that he is an integral part of the process. If you want the hoecake to be made in "de old Virginny way," which implies a tried and true method, one has to follow the instructions in the next two lines, or else it will not come out the right way. This metaphor is meant to show how important slaves and their labor are to plantations: without them, the plantation simply would not function. Masters wanted to believe that without their guidance, the plantation would fall apart and slaves would be

\section{"Like revolutionaries who killed a monarch or aristocrat and put his or her head on a pike to parade around the city, these slaves were parading a burning 'King Cotton' around the master's former kingdom."}

some sort of thanks for the food that the master gave the slaves. However, as the song goes on, one realizes that the slave is actually pointing out the unfair treatment that they get from their master, and that they really should not be grateful at all. ${ }^{87}$ The constant repetition of "we [action], dey gib us [lesser good]," shows not only the frequency with which this occurs, but the frustration the slaves have with their situation. The slaves are not happy and grateful to the masters, like the masters believe they are. This song shows a clear failure of the patriarchal system to convince slaves that they are lucky to be in the place that they are in. What it does demonstrate is that slaves used music as an outlet to express their discontent and to recognize the fact that they were important to the functioning of the plantation. Another song which shows slaves' awareness of this fact is a song that is disguised to be about making "hoecake." The three verses of the song are structured in the same way: the unable to support themselves, $9^{\circ}$ but these songs are the slaves' way of proclaiming the truth: without the slaves, there was no plantation, no wealth, and no South.

Finally, upon gaining freedom, many slaves throughout the South expressed their joy through the medium they themselves had helped to create: song. It was no longer possible for masters to claim that slaves had been happy under slavery since "dey was rejoicin' and singin" and "dey danced and had a big jamboree." ${ }^{\mathrm{I}}$ One of the songs slaves sang included the repetition of the line "T'ank ye Marser Jesus, t'ank ye" and "Jesus break slav'ry chain, Lord" multiple times, while describing the fact that the singer was no longer subject to repression from his master. ${ }^{2}$ The religious songs that once concealed slaves desires to be free now loudly proclaimed their joy that they were no longer the subjects of slavery. 
Some slaves however, were not happy to be free, or at least said in later interviews that they were not so. One man said that "slaves like us, what was owned by quality-folks, was sati'fied an' didn' sing none of dem freedom songs," 93 implying that he was sorry to have to be freed from a master whom he considered good. Another woman, whose mother had been enslaved, called the book Uncle Tom's Cabin a lie and said that slaves were sorry to be free. ${ }^{94}$ The reason for these radically different responses from those of other slaves could be because these people had internalized the racism that they experienced and truly believed their place was as a slave. They had a very romanticized view of the Old South, and they were not telling their interviewer the truth, since they thought he or she would not want to hear that they were glad to be free, or that they genuinely did like their master and were not mistreated. This last case is highly improbable, but not necessarily impossible, so it is worth noting.

These anomalies aside, slaves were on the whole overjoyed to be free. One very striking image of slaves reacting to freedom comes from the interview with Susan Bledsoe. She describes that she and other slaves "cut long poles and fastened balls of cotton on the ends and set fire to them. Then, we run around with them burning, a-singin' and adancin." 95 Burning cotton was not only literally destroying their master's property, but it was also symbolic of killing "King Cotton." Like revolutionaries who killed a monarch or aristocrat and put his or her head on a pike to parade around the city, these slaves were parading a burning "King Cotton" around the master's former kingdom. The addition of the songs and dances solidify this scene as a firm act of slaves expressing their autonomy and agency through the burning of the cotton as well as through their expression of the culture they created.

Hence, the struggle between slaves and masters to claim ownership of music and dancing on plantations ends with the slaves asserting their autonomy and sense of community both before and following emancipation. Their ability to subvert their masters' commands and wishes despite the day-to-day hardships they faced while enslaved is impressive and admirable. This is not to say that slaves' resistance completely negated any abuse their masters doled out to them; that interpretation romanticizes the realities of the antebellum South and ignores the suffering of thousands of human beings. These songs and dances helped to make living in a slave society just a little bit more bearable by drawing together a community of people in a common situation. No amount of music or dance steps could ever change the fact that slaves were held in bondage against their will, could ever bring back a sold family member, or could reverse the mistreatment of a master or overseer. What it could do was give slaves a fleeting moment of sense of self, pride, and identity that was otherwise lacking in their lives.

\section{ENDNOTES}

I. Isaac (2I6).

2. Joyner, Chapter 7 .

3. Wash Wilson Interview, Works Progress Administration Slave Narratives at the Library of Congress, hereafter cited as LOC-

WPA.

4. William Adams, LOC-WPA; Betty Bromer, LOC-WPA; Harriett Jones, LOC-WPA; Ellen King, LOC-WPA; Ida Rigley, LOC-WPA; Leithan Sprinks, LOC-WPA.

5. Alice Baugh, LOC-WPA; Susan Bledsoe, LOC-WPA; Betty Bromer, LOC-WPA; Harriet Jones, LOC-WPA.

6. Harriet Jones, LOC-WPA.

7. Betty Bromer, LOC-WPA.

8. Douglass (I8I).

9. Ibid.

Io. Wash Wilson Interview, LOC-WPA.

II. James Southall, LOC-WPA.

I2. For more about the blending of African Culture with

European Culture, see Joyner.

I3. Alice Hucheson, LOC-WPA.

I4. For more about Slave Religion, see Faust; Greenberg; Irons; Isaac; Joyner; Stevenson.

I5. Ellen King, LOC-WPA.

I6. Estella Jones, LOC-WPA.

I7. See Bibb.

I8. Sarah Douglas, LOC-WPA.

I9. Cf. Stevenson (i68).

20. For more about illness and medicine for slaves, see Faust; Isaac; Rothman.

2I. Mollie Williams, LOC-WPA.

22. Which, admittedly has much less emotionally heavy lyrics.

23. Mollie Williams, LOC-WPA.

24. Northrup (2I9).

25. Northrup (220).

26. Ibid.

27. For more about slave stories, see Joyner.

28. Northrup (2I9).

29. Ibid.

30. Tom Mills, LOC-WPA.

3I. Wash Wilson, LOC-WPA

32. Estella Jones, LOC-WPA

33. Ibid.

34. Stearns et al. (II).

35. William Adams, LOC-WPA.

36. Paul Smith, LOC-WPA.

37. Harriet Jones, LOC-WPA, Tom Mills, LOC-WPA; Paul Smtih, LOC-WPA. 
38. Paul Smith, LOC-WPA.

39. Alice Hucheson, LOC-WPA.

40. Ibid.

4I. Alice Hucheson, LOC-WPA.

42. For more on slave families and connections, see Dew; Joyner; Faust; McLaurin; Stevenson.

43. Paul Smith, LOC-WPA.

44. Douglass (6r).

45. Whether or not this practice was applied on most plantations, and whether or not this practice was effective is not for this author to judge, but Frederick Douglass wrote about it as an application of work songs. I was not there, and he was, so I will take his word for it.

46. Harriett Jones, LOC-WPA.

47, James V. Deane, LOC-WPA.

48. James Southall, LOC-WPA.

49. La San Mire, LOC-WPA.

50. Henry Walker, LOC-WPA.

51. Alice Hucheson, LOC-WPA.

52. Rachel Adams, LOC-WPA.

53. Sara Colquitt, LOC-WPA.

54. Rachel Adams, LOC-WPA, James V. Deane, LOC-WPA.

55. This is not to say that shucking corn is not difficult, as

this author struggles immensely with it. However, there is a

difference between planting cotton or tobacco in a hot field while standing all day, and shucking corn while sitting and singing with other members of the community.

56. Northrup (282).

57. Harriet Jones, LOC-WPA, Ibid 2I9.

58. For more about how masters tried to control and manipulate their slaves, see Drew Gilpin Faust, James Henry Hammond and the Old South., Kenneth S. Greenberg, The Confessions of Nat Turner and Related Documents., Rhys Isaac, Landon Carter's Uneasy Kingdom, Charles F. Irons, The Origins of Proslavery Christianity., Melton A. McLaurin, Celia, a Slave., Joshua D. Rothman, Flush Times \& Fever Dreams., Brenda E. Stevenson, Life in Black and White.

59. James Lucas, LOC-WPA.

6o. Douglass (182).

6I. Sara Colquitt, LOC-WPA.

62. Margaret Thornton, LOC-WPA.

63. Henry Walker, LOC-WPA.

64. Alice Hucheson, LOC-WPA.

65. James Southall, LOC-WPA.

66. Isaac (2I4-2I6)

67. Isaac (2I6).

68. Isaac (2I5).

69. As James Lucas said, "Marsters wid-out wives was de dabbil," James Lucas, LOC-WPA.

70. Bernice Bowden, LOC-WPA.

7I. Margaret Thorton, LOC-WPA.

72. Ibid.

73. Northrup (I8I).

74. Ibid.

75. Northrup (I8I-I82).

76. Northrup (I82). It should also be noted that Epps's wife was also entertained by his forcing the slaves to dance, so it would seem that she was not sincerely trying to make him stop what he was doing.

77. Ibid.

78. Brown (44)

79. Brown (44-45).

8o. Brown (5I).

8I. Northrup (2I7).

82. Ibid.

83. Douglass (84-85).

84. Wash Wilson, LOC-WPA.

85. Ibid.

86. Douglass (I96-I97).

87. Douglass (I82).

88. Harriett Jones, LOC-WPA.

89. Ibid.

9o. See Faust; Isaac.

9I. William Adams, LOC-WPA.

92. Harriett Greaham, LOC-WPA.

93. James Lucas, LOC-WPA.

94. Alice Baugh, LOC-WPA.

95. Susan Bledsoe, LOC-WPA.

\section{REFERENCES}

Bibb, Henry. Narrative of the Life and Adventures of Henry Bibb, An American Slave. Electronic Edition ed. New York: MacDonald \& Lee, Printers, I849.

Dew, Charles B. Bond of Iron: Master and Slave at Buffalo Forge. New York: W.W. Norton, I994.

Douglass, Frederick. Life and Times of Frederick Douglass, Written by Himself. His Early Life as a Slave, His Escape from Bondage, and His Complete History to the Present Time, Including His Connection with the Anti-Slavery Movement; His Labors in Great Britain as Well as in. Electronic Edition, New Revised Edition ed. Boston: De Wolfe Fiske \&, I892.

Faust, Drew Gilpin. James Henry Hammond and the Old South a Design for Mastery. Baton Rouge: Louisiana State University Press, 1985.

Greenberg, Kenneth S. The Confessions of Nat Turner and Related Documents. Boston: Bedford Books of St. Martin's Press, 1996.

Irons, Charles F. The Origins of Proslavery Christianity: White and Black Evangelicals in Colonial and Antebellum Virginia. Chapel Hill: University of North Carolina Press, 2008. 
Isaac, Rhys. Landon Carter's Uneasy Kingdom: Revolution and Rebellion on a Virginia Plantation. Oxford: Oxford University Press, 2004.

Joyner, Charles W. Down by the Riverside: A South Carolina Slave Community. Urbana: University of Illinois Press, I984.

Library of Congress.

McLaurin, Melton A. Celia, a Slave: A True Story. New York: Avon Books, I993.

Northup, Solomon. Twelve Years a Slave: Narrative of S. Northup, a Citizen of New York, Kidnapped in Washington City in 1841, and Rescued in 1853. [Edited by D. Wilson.]. Edited by David Wilson. Auburn: Derby and Miller, I853.

Rothman, Joshua D. Flush Times Q Fever Dreams: A Story of Capitalism and Slavery in the Age of Jackson. Athens, Georgia: University of Georgia Press, 2012.

Stearns, Marshall, and Jean Stearns. Jazz Dance: The Story of American Vernacular Dance. New York: De Capo Press, I968.

Stevenson, Brenda E. Life in Black and White: Family and Community in the Slave South. New York: Oxford University Press, 1996. 